Mavi Atlas, 7(2)2019: 201-219

Makale Geliş | Received: 16.09.2019

Araştırma Makalesi | Research Article

Makale Kabul | Accepted: 29.09.2019

DOI: $10.18795 /$ gumusmaviatlas.620682

Hanife SARAÇ

Dr. Öğr. Üyesi| Assist. Prof. Dr.

Karadeniz Teknik Üniversitesi, Edebiyat Fakültesi Rus Dili ve Edebiyatı Bölümü, Trabzon-TÜRKİYE

Karadeniz Technical University, Faculty of Letters, Department of Russian Language and Literature, Trabzon-TURKEY

ORCID: 0000-0001-8280-4624

hanifecaylak@ktu.edu.tr

\title{
Sovyet Rusya'da “Öteki”nin Yeniden İnşası Sürecinde Olumsuz Adlandırmalar
}

Öz

Sovyet iktidarı sosyalist düzenin tam manasıyla işlemeye başladığı İç Savaş sonrası dönemde kolektif kimliğin şekillenmesi için çaba göstermiştir. Bu bağlamda yeni sosyal gerçeklikle birlikte şekillenen "biz" ve "öteki" kimliklerinin oluşumuna katkı sunan unsurlardan biri de olumsuz adlandırmalar olur. Parti'nin güçlenme döneminde sosyalist ideolojinin cephe aldığı kapitalistler ve burjuva sınıfı "öteki" ilan edilirken, İç Savaş sonrası dönemde ise kendilerine muhalefet eden tüm birimler Sovyet halkının karşısında konumlandırılarak "öteki”"leştirilir. "Biz"den olan vatansever, ülke için çalışan, düzenin koruyucusu iken diğer tarafta "öteki" sosyal düzeni bozan, ülkesine zarar veren ve halk düşmanıdır. Sosyalist düzen oturtulmadan önce daha çok Bolşevik lider kadrosunun söylemleri üzerinden işleyen bir dışlama mekanizması etkinken, ilerleyen dönemde yaftalama ve etiketleme şeklinde yürütülen bir "ötekileştirme" süreci dikkat çeker. Bu çalışmada Sovyetlerce geliştirilen "istenmeyen"in "öteki”'leştirilmesi yaklaşımı üzerinde durulmakta, bu süreçte istifade edilen ve olumsuz adlandırmalara örnek teşkil eden kelimeler incelenmektedir.

Anahtar Kelimeler: Öteki, Olumsuz Adlandırma, Sovyet Rusya.

\section{Negative Nomenclature in Soviet Russia in the Process of Reconstruction of "The Other"}

\begin{abstract}
In the post-Civil War period when the socialist order began to function in full sense, the Soviet power strived to shape the collective identity. In this context, one of the factors contributing to the formation of "us" and "the other" identities formed with the new social reality is negative nomenclature. In the period of empowerment of the Party, the capitalists and the bourgeois class, which were sided against by socialist ideology, were declared "other", while all opposing units were positioned against the Soviet people and as "other" in the post-Civil War period. The patriot, who is one of "us" and works for the country, is the protector of the order, but on the other side "the other" disrupts social order, harms his/her country and is an enemy of the people. In the following period, a process of "otherization" by labelling draws attention. This study focuses on the approach of "otherization" of "unwanted" developed by the Soviet Union and the words that are used as examples of negative nomenclatures in this period are examined.
\end{abstract}

Keywords: The Other, Negative Nomenclature, Soviet Russia. 


\section{Giriş}

Rusya İmparatorluğu'nun XIX. yüzyıldaki siyasi çalkantılarla gerektiği gibi başa çıkamaması Çarlık'ın tarihe gömülmesi sonucunu doğurmuştur. Birinci Dünya Savaşı'nın getirdiği ağır koşullar ve öncesinde Japonya ile girilen savaş, tarihte kurulacak ilk sosyalist devletin mayasını hazırlayan koşullar olmuştur. Rejimin topyekûn değişmesi anlamına gelen Ekim Devrimi'nin gerçekleşmesiyle toplumsal yapı unsurlarının yeniden şekillendirilmesi zorunlu hâle gelir. Hâkim sınıfın önünde yeni sosyalist düzenin tesis edilmesi gibi büyük bir görev durmaktadır. Monarşinin geride bırakıldığı yeni sosyalist düzen içerisinde siyasal, sosyal ve ekonomik anlamda bir kabuk değişimi söz konusudur. Sosyalist rejimin gerçeklerine göre düzenlenmesi gereken toplumsal yaşam planı güçlü bir propaganda sisteminin planlanmasını zorunlu kılar. Birinci Dünya Savaşı'nda kullanılan propagandanın tesir gücünü gören Bolşevik liderler propagandaya büyük önem atfeder (Can Emir 2019: 41-44). Her şeyden önce psikoloji ve sosyolojinin bilimsel analizlerine dayanan propaganda hiyerarşik bir düzen içerisinde tesis edilerek zamanla ülkenin bütün damarları hâlini alır ve Bolşeviklerin en güçlü silahı olarak adlandırılır (Ellul 1973: 4). Sovyet propagandasının başarısının temelinde halkın psikolojisinin çok iyi analiz edilmiş olmasının yattığı görülmektedir (Krısko 1999: 347). Propagandanın birincil iletkeni olan yeni dilin inşasında bütün sosyolojik ve psikolojik değişkenler gözetilir. İktidar, dil üzerinden sürdürülen ve temellendirilen yeni totaliter düzende halkın bütünlüğünü garantilemek ister. Bu birlikteliğin önemini siyaset bilimci Halis Çetin şu sözlerle ifade eder: "Çünkü birlik, bütünlük ve uyum siyasal iktidara bütüncül bir iktidar alanı yaratarak total bir evrenin düzenlenmesi imkânı verir. Siyasal iktidar ile toplumsal itaatin birlik ve bütünlüğü bu imkânı güçlendirir. Bu durum, siyasal iktidarın meşruiyet yasasına mutlaklık ve kutsallık katar." (Çetin 2002: 23).

Dil üzerinde yapılan değişikliklerle topluma tek tip bakış açısı kazandırılmaya çalışılır. Söz konusu değişiklikler çerçevesinde yeni sözlüklerin hazırlatılması yoluyla kavramlar anlam erozyonuna uğratılarak, yeni sözcükler üzerinden algı ve çağrışımlar manipüle edilir. $\mathrm{Bu}$ uygulamalar dilin söz varlığında değişiklikler meydana getirir. İktidarın yeni organlarının, toplumsal kurumların, ekonomi ve kültürdeki değişikliklerin adlandırılması da yeni sözcüklerin ortaya çıkmasını beraberinde getirir. Sovyet Dönemi'ne has olayları, kişileri, nesneleri vs. tanımlayan isimler olan sovyetizmler (советизмы) ortaya çıkar. Gazete ve evrak dilinde halkın büyük bir kısmının anlamadığı yabancı dilden alıntı sözcükler yaygınlaşır. Sembol ve metaforlar iktidar lehine suistimal edilir. Sıkça muğlak ifadeler kullanılır. Gazete diline ve resmî konuşma diline hapishane jargonundan sözcükler geçer. Kısa bir süre önce anlamlı ve önemli olan sözcükler 
Hanife SARAÇ, “Sovyet Rusya'da 'Öteki'nin Yeniden İnşası Sürecinde Olumsuz Adlandırmalar”, Mavi Atlas, 7(2)/2019: 201-219

zamanın gerçekliğinde kendine yer bulamayarak anlamını yitirmeye başlar. $\mathrm{Bu}$ değişiklikler temelinde şekillenen yeni evrende rejimin meşrulaştırılması esastır. Çünkü Platon'un da ifade ettiği gibi, "İyi olan, yararlı olan, yapılması gereken tek şey devlet için en iyi, en yararlı olandır. Çünkü toplumsal birlik ve bütünlüğün teminatı olan devlet için yararlı olan herkes için yararlıdır." (Platon 1995: 80). İktidar, kurmuş olduğu Propaganda Bakanlığ1 ve alt birimleri sayesinde hedeflerini büyük ölçüde gerçekleştirir. Öyle ki Sovyet Rusya'dan "Propaganda Devleti” şeklinde bahsedilmeye başlanır. Son tahlilde birlik, bütünlük ve uyumun koruyucusu siyasal iktidar ile toplumun ortak düşmanları olan bireysellik, çoğulculuk, parçalanmışlık, uyumsuzluk ve bölücülük bu düzenin dışına atılır. "Biz" ve "onlar" arasındaki çatışma "biz"i “onlar"a karşı ortak bir savaş hedefinde ve ideolojik bir çerçevede en çok kaynaştıran temel temaya dönüşür. Bu çatışma ideolojisi ile totaliter iktidar halkın sadece politik desteğini değil kayıtsız şartsız sadakatini de sağlamış olur. Bu yüzden harici ve dâhili düşmanlar totalitarizmin en vazgeçilmez temalarını oluşturur (Hayek 1999: 188).

Bu çalışmada "biz" ve "öteki”yi yeniden inşa etmek üzere Sovyet yönetiminin istifade ettiği olumsuz adlandırmalar incelenmektedir. İlk olarak, “öteki” kavramının devrim öncesinde ve sonrasında ifade ettikleri analiz edilmekte, sonrasında bu kavramın hayat bulmasında önemli rolü olan olumsuz adlandırmalar örnekler üzerinden açıklanmaktadır.

\section{Ekim Devrimi Öncesinde ve Sonrasında “Öteki”' İmgesi}

Önceden hafızalara yerleşmiş belli imgeler, klişeler ve ön yargıları ifade eden öteki kültürü, Ekim Devrimi’yle birlikte yeniden inşa edilir. Rus sosyolog Andrey Zdravomıslov bütün sosyal dünyayı "biz" ve "ötekiler"e ayıran belirli kriterlerin bulunduğunu, düşman imgesinin yaratılışının, çatışmanın ideolojik boyutunun yaratılışıyla ilişkili olduğunu dile getirir. Barışçıl bir yol izleme eğiliminde olan tarafsız güçler de karşı cenaha dâhil edilir (Zdravomıslov 1996: 97-98). Sosyal psikoloji uzmanı Nuri Bilgin (2007)'e göre ötekileştirmenin dört temel fonksiyonu vardır:

- Kimlikleştirme: Bireyler, bir düşmanı veya ötekini referans alarak kolektif kimliklerini inşa etmektedirler.

- $\quad$ Kimlik Yüceltme: Dış grupların ötekileştirilerek negatif özelliklerin bu gruplara atfedilmesi, grup içinde kalan bireylerde arınma, rahatlama ve kendini beğenme duygularına yol açmakta ve dolayısıyla gruptaki bireylere pozitif bir kimlik kazandırmaktadır. 
Hanife SARAÇ, “Sovyet Rusya'da 'Öteki'nin Yeniden İnşası Sürecinde Olumsuz Adlandırmalar”, Mavi Atlas, 7(2)/2019: 201-219

- $\quad$ Meşrulaştırma: Sosyal özdeşleşme ve sosyal kıyaslama neticesinde grup içinin değerlerinin olumlanması ve tüm olumsuzlukların grup dışına yansıtılması, grup içinin değer yargılarını ve grup üyelerinin diğerlerine yönelik olumsuz tutum ve davranışlarının haklı gösterilmesine ve meşrulaştırılmasına sebep olmaktadır.

- $\quad$ Sosyal Düzeni Koruma: Olumsuzluklar diş gruplara yüklendiğinden, sosyal düzeni bozanların ötekiler olduğu inancı genele yayılmakta ve dolayısıyla ötekilerin kontrol altına alınması durumunda sosyal düzenin sorunsuz işleyeceğine inanılmaktadır.

Bir takım düşmanların varlığı grup üyelerinin etkili bir şekilde bir araya gelmesinin olmazsa olmaz unsurudur. Yaşamsal menfaatlerden biri olarak bu birliğin oluşturulması gerekir, hatta kimi gruplar için bu birlik bilgelik emaresi bile sayılabilmektedir (Simmel 1956: 98). Özellikle kimlik farklılıklarına dayalı politika yapma sürecinde ötekileştirme, çoğulcu toplum yapısında sorunsallaştırılması gereken bir kavram olarak karşımıza çıkmaktadır. "Biz” açısından "öteki”yi tanımlayan en önemli özellik düzen bozma potansiyelidir. "Biz" ne kadar istikrarsızlık getirmeyecek olan, düzenin yeniden üretimini sağlayan ve bu nedenle toplumun var oluş amacina uyansa "öteki” de o kadar düzen bozma, istikrarsızlık getirme, düzenin işleyişini sağlayan gelenek, yasa, normların içini boşaltma potansiyeline sahip olandır, yani tehlikeli olandır (Kundakçı 2013: 69).

Öteki, siyasi ve sosyal değişikliklere paralel olarak yeniden anlamlandırılır. Çünkü yaşanan sosyolojik değişiklikler kimlikleri de etkilemekte ve kimliklerin şekillenmesinde rol oynamaktadır. Nitekim Sovyet Rusya'da Bolşeviklerin devrim öncesi ve devrim sonrasındaki “öteki” algısı da değişiklik gösterir. "Biz” ve "öteki” kavramları toplumun düşman sınıflara bölündüğü Bolşevik teorinin temelini teşkil eder. Bolşeviklerin, devrim öncesi ve sonrası dönemde Sovyet totaliter politik söylemlerindeki "biz" ve "öteki” kavramlarının taşıdığı anlamı aralayan anahtar sözcükler vardır. Bu anahtar sözcüklerden biri olan Stnıf Teorisi (классовая теория), toplumu devrim henüz gerçekleşmeden bölmüştür. Rus sosyal demokrasi propagandasındaki dünya modeline göre proletarya ve kapitalistlerin karşı karşıya geldiği bir toplum söz konusudur (Korobkova 2011: 99). Dimitri Uşakov'un sözlüğünde sınıf maddesi, “Üretim araçlarına aynı pencereden bakan, ekonomik çıkar çatışmaları bağlamında diğer sosyal grupların karşısında yer alan, ortak çıkarların birleştirdiği sosyal grup, toplumun bir bölümü” sözleriyle karşılık bulur (Uşakov 2006: 348). İosif Stalin'in devrim öncesi öteki algısına 1şık tutacak şu sözleri sınıf ayrımı noktasında oldukça keskindir (Stalin 1946: 331-332): 
Günümüzdeki yapı kapitalizm adını taşıyor. Bu, bir avuç kapitalist ve çoğunluğu teşkil eden proletarya olmak üzere dünyanın iki rakip kampa ayrıldığına işaret ediyor. İşçiler gece gündüz çalışıyor, buna karşılık fakir kalmaya devam ediyor. $\mathrm{Bu}$ durum, işçilerin zekâdan yoksun olmasından ya da kapitalistlerin dâhi olmasından ileri gelmiyor, kapitalistlerin işçilerin emeklerinin üzerinden geçinmesi ve işçi sınıfını sömürmesinden ileri geliyor.

Yine D. Uşakov’un sözlüğünde proletarya (Kapitalist ülkelerdeki) "Silah ve üretim faktörleri mülkiyetinden mahrum kiralık işçi” ve "kapital, işçi gücünün sömürülmesi suretiyle sahibine yani kapitaliste haksız kazanç sağlayan değer" şeklinde tanımlanır (Uşakov 2006: 71-375). D. Uşakov’un insanın sosyal statüsüne vurgu yapan tanımlamalarında kapitalistler ve proletarya aşağıdaki sözcükler üzerinden karşı karşıya getirilmektedir (Korobkova 2011: 99):

$\begin{array}{lll}\text { Proletarya } & <> & \text { Kapitalistler } \\ \text { Çoğunluk } & <> & \text { Azınlık } \\ \text { Çalışıyorlar } & <> & \text { Çalışmıyorlar } \\ \text { Fakirler } & <> & \text { Zenginler }\end{array}$

Bunların yanı sıra İç Savaş yıllarından itibaren "biz” köylüler, “ötekiler” ise toprak sahibi zenginlerdir (Korobkova 2011: 99). Bolşeviklerin ideolojisi eski dünyanın tamamen yok edilmesini ve yerine zengin ve fakir ayrımının ortadan kaldırılarak, genel bir eşitliğin sağlanmasını öngörmüştür. Buradan hareketle "bizimkiler" kavramı yeni dünyayla, "öteki" ise eski dünyayla ilişkilendirilir (Korobkova 2011: 100). Yeni dünyanın propagandasında proletarya diktatörlüğü yer almaktadır. Bu durumda "yeni”, toplumun sosyal olarak en savunmasız hatta hakları olmayan kesiminin iktidarıdır. Nitekim işçi ve köylüler Çarlık Rusya'da hiçbir siyasi hakka sahip değildir (Kratkiy Kurs. İstoriya vserossiyskoy kommunistiçeskoy partii bol'şevikov 1950: 6). Çarlık monarşisi eski dünyayı temsil etmektedir ve eski iktidarla bir şekilde ilintili olanlar (ilk başta da dvoryanlar) ${ }^{1}$ artık "öteki” tarafında konumlanır. En tehlikeli düşmanlardan biri olarak burjuvazi gösterilir. V. Lenin ve İ. Stalin'in burjuvaziye yaklaşımı şöyledir: "Burjuvazi bizim amansız düşmanımızdır. Burjuvazinin zenginliği, bizim yoksulluğumuz, mutluluğu acımız üzerinde yükselmektedir. Bizi, bile isteye ezmeye çalışacak olan burjuvazinin bilinçli temsilcilerinin bizim can düşmanlarımız olacağı aşikârdır” (Stalin 1946: 179184). "Burjuvazi ikiyüzlü olmak ve pratikte emekçilerin üzerindeki burjuva diktatörlüğü,

\footnotetext{
${ }^{1}$ Feodal toplum düzeninde Rus asilleri, toplumun ayrıcalıklı kesimi.
} 
sömürge diktatörlüğü olan varlığını demokrasi hatta tam bir demokrasi olarak tanımlamak zorunda" (Lenin 1915: 388-393). "Liberal burjuvazinin her şeyden çok korktuğu işçi ve köylülerin üzerinde bir kırbaç olarak gördüğü Çarlık iktidarına ihtiyaç duyduğu aşikâr, bu devrimin zaferi liberal burjuvazinin bu yüzden işine gelmiyor" (Stalin 1946: 179-184). "Onlara göre Çarlık, burjuvazinin proletaryaya karşı kullandığı en güvenilir kalesi olarak devam ettirilmeli." (Stalin 1946: 180).

Devrimin ilanıyla birlikte ilk olarak dvoryanlar ve toprak sahipleri "öteki” olarak kodlanmaya başlanır. Devrim öncesi siyasi söylemde entelijensiyanın "biz" ve "öteki" grubuna dâhil edilmediği görülür. Onlar, Proletarya ve köylülere has olan sınıf birliği içinde değerlendirilmezler (Korobkova 2011: 100). Ancak Vladimir Lenin bazı söylemlerinde entelijensiya ile ilgili negatif kodlamalar yapmaya başlar: "Kapitalist toplumların özel bir bölümünü oluşturan entelijensiyanın genel itibarıyla disiplin ve organizasyona yetisi olmadığını, bireyciliğini kimse inkâr etmeye kalkamaz. Partimizdeki işçilerin değil de kimi entelektüellerin disiplin ve organizasyon ruhu eksik" (Lenin 1967: 254). V. Lenin, Ekim Devrimi'ne zemin hazırlayan bazı siyasi figürlerin dışında entelijensiyaya şüpheci, tedbirli ve mesafeli yaklaşır. V. Lenin'in bu yaklaşımını entelijensiyanın 1905 Devrimi’ne karşı çıkması gibi psiko-sosyolojik bir nedene dayandırmak mümkündür. Sovyetler Birliği'nin dağılmasıyla açılan arşivler devrim yanlısı yazar ve şairlerin bile kimi zaman içten içe derin bir muhalefet içinde olduğunu göstermiştir. M. Gorki'nin “Entelijensiya halkın beyni ve rengidir” sözüne cevaben V. Lenin "Halkın beyni değil, dışkısıdır" (Lenin 1978: 48,49) demiştir. V. Lenin'in entelijensiyaya bakışını gösteren en çarpıcı diyaloglardan birisi V. Lenin ve ressam Yu. P. Annenkov arasında yaşanır. V. Lenin, kendisinin portresini çizen Yu. Annenkov'a "Biliyor musunuz ben sanattan pek anlamam. Sanat benim için bir nevi kör bağırsak. Sanat, bizim olmazsa olmazımız olan propaganda işlevini bitirdiğinde onu böyle kıtır kıtır keseceğiz! Başka bir işlevi olmadığından mütevellit..." ifadelerini kullanır (Annenkov 1991: 247).

Sosyalist Devrimciler Partisi (Па́ртия социали́стов-революционе́ров) ve Bolşevikler arasında devrimin lokomotif gücünü hangi sınıfın taşıyacağı yönündeki fikir ayrılıkları da partiler arası ötekileştirmeye zemin hazırlar. Sosyalist Devrimciler için lokomotif gücü oluşturması gerekenler köylüler iken Bolşevikler için bu güç proletaryadır. Bolşevikler bu görüşlerini, köylülerin aralarında bölünmeler yaşandığını ve organize olamadıklarını ancak düzensiz küçük ayaklanmalara yetileri olduğuna dayandırır. Komünist Parti'nin ileri gelenleri arasında partiye üyelik koşulları hususunda 
Hanife SARAÇ, “Sovyet Rusya'da 'Öteki'nin Yeniden İnşası Sürecinde Olumsuz Adlandırmalar”, Mavi Atlas, 7(2)/2019: 201-219

da itilaflar baş gösterir. Siyasette görülen bu tarz muhalif hareketler tarafların "biz" ve “öteki” şeklinde ayrıştırılmasına sebep olur.

İç Savaş’ın geride kalması ve sosyalist rejimin tam anlamıyla tesis edilmesi sonrasında “öteki” kavramı düşmana evrilir. Düşman sözcüğü Sovyet Rusya'da kendisine oldukça geniş bir kullanım alanı bulur. Düşman, Sergey Ojegov'un hazırlamış olduğu sözlükte "birisiyle düşmanlık halinde bulunan kimse, hasım" olarak tarif edilmektedir (Ojegov 1952: 85). Totaliter rejime göre ise düşman, halkın karşısında olan kimse anlamındadır ve burada halk ifadesiyle kastedilen tüm Sovyet nüfusudur. Halk, yönetimdeki partinin değişmez müttefiki olarak addedilir. İktidar ne pahasına olursa olsun düşmandan ayıklanmalıdır. Burada verilmek istenen mesaj, mevcut yönetime muhalefet edenlerin halkın düşmanı olduğu şeklindedir. Bu kullanımla birlikte siyasi düşünce düşmanları ile halk düşmanları arasındaki çizgi zamanla belirsiz hâle gelir (Korobkova 2011: 101).

Ekim Devrimi öncesi dönemde ve Sovyet totaliter sisteminin yerleşmesinden sonraki dönemde "biz" ve "öteki” kategorileri arasında önemli ölçüde farklılıklar gözlemlenmiştir (Korobkova, 2011:101):

1. Sovyet totaliter söyleminde “öteki”, "biz"den daha dinamik bir şekilde gelişir ve bu gelişme kendisini sözcüksel düzeyde gösterir. Diğer bir deyişle "öteki”yi temsil eden adlandırmaların sayısı artar.

2. "Biz" ve "öteki” arasında kimi zaman anlaşılması güç, silik bir sınır bulunur ve bu sözcüksel düzeyde yansır.

3. Halkın zihninde "öteki””lere karşı nefret uyandırmak amacıyla negatif değerlendirme içeren sözcükler kullanılır.

4. “Öteki” kategorisi "biz” kategorisi karşısında zenginleşir, hatta iktidarın güvenini yitirmiş özel isimler kullanılır, hedef gösterilir.

Özetle; devrim öncesinde oluşturulan “öteki” profili zamanla etiketleme sözcükleri üzerinden genişletilir. "Biz"den sayılanın zamana ve duruma göre "öteki” grubunda değerlendirildiği de görülür. İki grup arasındaki perdenin oldukça ince olduğu durumlar sözcüklerin kullanımında kendini gösterir.

\section{Partinin Gelişiminde "Biz" ve "Öteki"}

Sovyetler Birliği Komünist Partisi, (ВКП: Всесоюзная коммунистическая партия (большевиков)) işçi hareketi içinde yer alan küçük burjuva partileriyle; Menşeviklerle, anarşistlerle, her türlü burjuva milliyetçileriyle; parti içindeyse Menşevik 
oportünist akımların destekçisi olan Troçkicilerle, Buharincilerle ve diğer anti-Leninci gruplara karşı verdiği mücadele sonucunda büyüyerek güçlenmiştir (Kratkiy Kurs. İstoriya Vserossiyskoy Kommunistiçeskoy Partii Bol'şevikov 1945). Komünist Partisi siyaset dışında ise emekçilerin bütün düşmanlarıyla (toprak sahipleriyle, kapitalistlerle, zengin köylülerle, ispiyoncularla, kapitalist güçlerin kiraladığı adamlarla) mücadele ederek güçlenir ve yerini sağlamlaştırır. Bu örneklerde hem siyasi düşmanlar hem de halk düşmanları yani işçi sınıfının, emekçilerin düşmanları yer almaktadır. İktidarın düşmanlarıyla yegâne ve en etkili iletişimi, onlarla mücadele hâlinde olmaktır. Sovyet totaliter söyleminde mücadele her şeyden önce hasmı yok etme biçiminde kendisini gösterir. Bununla birlikte hem siyasi hem de halk düşmanlarını yok etme hevesi yaygınlık kazanır. Halk düşmanlarını, "parti içi düşmanlar" ve "zararcılar" adı verilen grup olmak üzere iki kategoriye ayırmak mümkündür. Partinin genel çizgisini desteklemeyip İ. Stalin'le polemiğe girenler parti içi düşmanlar olarak değerlendirilir (Korobkova 2011: 101). Bu grupla ilgili olarak İ. Stalin, "Partinin çizgisi tek olmasına rağmen yoldaşların bir kısmının tarım politikalarıyla ilgili genel meselelerin oylanmasını reddetmesi nasıl oluyor? Hayır, yoldaşlar, yeryüzünde öyle mucizeler olmuyor" ifadelerini kullanır. (Stalin 1949: 1-107). Sovyetlerde parti içi düşman olarak görülenler genel itibarıyla Nikolay Buharin, Lev Troçki, Grigori Zinovyev gibi farklı Bolşevik liderlerin destekçileridir.

Toplumun geneline ters düşen fikir ve davranışları bertaraf etmek isteyen iktidar yeni kimliklerin ("biz”, “öteki”) inşasında stereotiplere ve ön yargılara ihtiyaç duyar. Bu noktada olumsuz adlandırmalar Sovyet Rusya'da ötekinin önemli unsurlarından olan stereotiplerin ve ön yargıların pekişmesini sağlar. $\mathrm{Bu}$ adlandırmalar Sovyet sözcük dağarcığında hazır bir şekilde yer almamış, yaşanan sosyolojik ve psikolojik deneyimler neticesinde oluşmuştur. Basında ve günlük konuşma dilinde yayılan bu sözcükler "biz" ve "öteki” arasındaki mesafenin sınırlarını çizer. Egemen sınıf kendi "bizi”ni oluştururken birtakım taktikler geliştirir, çoğu zaman abartıya başvurur. Zira birey kendi grubu ve öteki grupta yer alan üyeler arasındaki farklılıkları abartılı bir biçimde sunmayı amaçlamaktadır (Sakallı 2010: 180). Olumsuz adlandırmalar, insanın dış dünyayı anlaması için kalıp yargılar olan stereotiplerin oluşumuna büyük katkı sunar. Amerikalı yazar, gazeteci Walter Lippmann'a göre algılar düzeyinde beliren stereotipler, ön yargının oluşmasına etki etmekte ve her ikisinin bileşimi kolektif kimliği şekillendirmektedir. Ön yargı kavramını belirli bir dış grup hakkındaki olumsuz dogmatik kanaatler olarak tanımlayan sosyal psikolog Henri Tajfel; sosyal kategorizasyonun, asimilasyonun ve kavramsal bağdaşımın birleşerek ön yargıları şekillendirdiğine 
değinmiştir (Tajfel 1969: 173'den aktaran Ünür 2013: 256). Stereotipler zaman içinde ön yargıları oluşturmakta, bu ön yargılarsa olumsuz davranışlara dönüşerek dış grubu ekonomik, politik ve sosyal alanda dezavantajlı bir duruma sokan toplumsal dışlamaya diğer bir tabir ile ayrımcılığa yol açmaktadır (Bilgin 1996: 98). Bu zihinsel kavramsallaştırma zaman içinde “onlar”'1n yabancılaşarak ötekileştirilmesine neden olmaktadır. Diğer bir ifadeyle, kimliğin zihinsel üretimi; iyi özelliklerle yüklü "biz”i ve kötü özelliklerle yüklü “öteki”ni yaratmaktadır (Ünür, 2013:257). Ortalama vatandaşlar hazır sunulan stereotiplerden istemli ya da bilinçsiz bir şekilde etkilenmekte ve bunlara göre davranış biçimleri geliştirmektedirler. Bu noktada kodlama vesilesi olan olumsuz adlandırmalar iktidarın araçları tarafından kullanılabildiği gibi halk tarafından da kullanılmaktadır. Diğer bir deyişle olumsuz adlandırmalar iktidar için hâkim ideolojinin değer yargılarıyla örtüşmeyen özellikleri bertaraf etmek üzere bir nevi etiketleme yoludur. İktidar tarafından kullanılan bu tür olumsuz adlandırmalara aşağıdaki kelimeler örnek olarak verilebilir:

Poprıun (попрыгун): Tutarlı bir kişiliğe sahip olmadığı için sürekli işyerini değiştiren, kendisini gerçekleştirme yetisi olmayan, sürekli yenilik ihtiyacı hisseden, önemli veya sorumluluk gerektiren bir süreçte dahi herkesi, her işi bırakabilme potansiyeli olan kişi. Ciddiyetsiz, sorumsuz, güvenilmez, herhangi bir işte bel bağlanılmaması gereken, doğası gereği yöneticiliğe veya bir işin sorumluluğunu üstlenmeye uygun olmayan kimse (Tolokovıy slovar' russkogo yazıka [TSU]).

Lobotryas (лоботряс): Gücü ve fiziksel yeterliliği olduğu hâlde çalışmayan, gerektiği gibi okumayan, eğlenceye zaman ayıran, toplum için yararlı bir iş yapmayan delikanlı, genç adam. Topluma fayda sağlayacak her türlü faaliyetten uzak yaşayan, bu yönüyle toplum önünde rahatsızlık, utanç veya sorumluluk hissetmeyen, vicdanı rahat kimse. İş yerinde iş planına riayet etmemesi, işin kendisine düşen payını da çalışma arkadaşlarına yüklemesiyle sonuçlanmakta ve kötü bir intiba oluşturmaktadır (Çervinski 2012: 170-171).

Brakodel (бракодел): Sorumsuz çalışan, işten bir an önce kurtulma hevesiyle hatalı iş çıkaran, kaliteli ürün çıkarma kaygısı gütmeyen, defolu mal, ürün teslim eden kimse (Çervinski 2012: 95-96).

Bay (бай): Doğu'nun emekçi köylülerini sömüren, Sovyet iktidarının sınıflar arasındaki farkların ortadan kaldırılması için 1920-1930 yıllarında vermiş olduğu mücadeleye karşı çıkan doğulu bey. Sovyet Asya'sı ve Doğu'sunun ayrıcalıklı, emekçi olmayan, emekçi hemşerilerine tepeden bakan, çalışmamak için sosyal statüsünü 
kullanan, halkını hor gören, emeğini küçümseyen kesiminin temsilcisi. Sovyet iktidarını ve onun feodal Asya ve Sibirya'daki başarılarını gözden düşürmek için çabalayan kişi (Çervinski 2012: 83).

dvuruşçnik (двурущник): İşçi davasına, sosyalizm ideallerine sadık, ilerici fikirlere hizmet etmeye hazır, sosyalizm yanlısı gibi görünüp aslında düşmana, kapitalizme ve sömürücü kesime hizmet eden, siyasi ikiyüzlülük yapan, işçi sınıfı saflarında yer alıp yıkıcı faaliyetlerde bulunarak partisine ve yandaşlarına ihanet eden (Çervinski 2012: 126).

basmaç (басмач): 1917-1933 yılları arasında Orta Asya'da (Türkistan, Harezm, Buhara) Panislamist ve Pantürkist hareketin içinde yer alarak Sovyet iktidarına karş1 silahlı direniş gösteren kişi (Çervinski 2012: 86).

Halk tarafından kullanılan olumsuz adlandırmalar ise sistemdeki olumsuzluklara, açıklara, ideolojinin pratikte doğru bir şekilde işlememesine getirilen eleştiriler olarak ortaya çıkmaktadır:

miroyed (мироед): 1.Özellikle Sovyet iktidarının ilk yıllarında zengin köylü, toprak ağası, tefeci anlamında kullanılan bir sözcüktür. Başkalarının emeklerini sömürerek, onları neredeyse karın tokluğuna kendileri için çalışmaya zorlayan, yüksek faizlerle borç para veren, onların yoksulluğu üzerinden zenginleşen kimse. 2. Hâli vakti yerinde olan, zenginleşen, hile ve entrikalarla lüks içinde yaşayan, insanları onların zor durumlarından faydalanarak onlara başka seçenek bırakmayarak kendilerine mecbur bırakan, tamamen kendi inisiyatifine ve yoksulluğa mahkûm eden kişi (Çervinski 2012: 179).

duşitel'(душитель): 1. Yüksek iktidar temsilcisi, en küçük bir ayaklanmay1, memnuniyetsizliği bastırmaya çalışan, baskı yapan, mevcut rejime açıktan karşı çıkanları ya da sadece şüphelendiklerini fiziksel olarak yok eden katil, tiran, diktatör. 2. Hiyerarşik açıdan altında bulunan işçileri, takipçilerini ve öğrencilerini, en ufak bir özgünlüğe, özgürlüğe, özgün sanata tahammülü olmadığı için takip eden, kovan, ortadan kaldıran, yönetici, müdür, usta, ekip başı, üniversite hocası, profesör (Çervinski 2012: 127).

volınşçik (волынщик): Halledilmesi kendisine bağlı bir işi erteleyen, yavaşlatan, yürümesine engel çıkaran devlet çalışanı (Çervinski 2012: 104).

golovotyap (головотяп): Sert, aptal anlayışsı, özensiz, beceriksiz, savsak. Buna rağmen bulunduğu mevkii hak ettiğini ispata çalışırcasına herkesin her işine burnunu sokan yönetici, müdür, ekip başı (Çervinski 2012: 117). 
Hanife SARAÇ, “Sovyet Rusya'da 'Öteki'nin Yeniden İnşası Sürecinde Olumsuz Adlandırmalar”, Mavi Atlas, 7(2)/2019: 201-219

Komitetçik (комитетчик): Halka ve sorunlarına uzak, yokluğun ne olduğunu bilmeyen, salt kariyerine odaklı, ruhsuz, inatçı parti komitesi üyesi. (Çervinski 2012: 154)

Rusya'da doğup çalışmalarına Polonya'da devam eden dilbilimci Pyotr Çervinski kişi adlandırmalarıyla ilgili kapsamlı çalışmalarından birinde olumsuz adlandırmaları dört ana başlık altında değerlendirir:

Birinci grupta yer alan sözcükler Sovyet dünya görüşü açısından kabul edilemez, negatif anlam yüklü sözcüklerdir ve genellikle zamanın kitle iletişim araçlarında göze çarpmaktadır. Kişiye isnat edilen bu ötekileştirici sözcükler genel itibarıyla bir işin, çalışmanın yürütülmesine getirilen eleştiriler sonucu kullanılmaya başlanmıştır. Rejimin hoş görmediği sıfatları içinde barındırmaktadır:

Alliluyşçik (Аллилуйщик): Birine ya da bir şeye ölçüsüzce övgüde bulunan kimse (Tolkovıy slovar' yazıka sovdepii [TSYAS] 1998).

Lakirovşçik (Лакировщик): Gerçekliği olduğundan daha cazip, etkileyici ve parlak gösteren kimse (Bol'şoy tolkovıy slovar' [BTS] 2000).

Pereverten' (Перевертень): İnancını, dünya görüşünü ya da alışkanlıklarını sıkça değiştiren kimse (Slovar' russkogo yazıka v 4-h tomah [MAS] 1981-1984).

Truten’ (Трутень): Erkek arı. Hiçbir üretimde bulunmayan, bir işte çalışmayan, başkalarının üzerinden geçinen kimse (TSU 1935-1940).

Perebejçik (перебежчик): Düşman tarafına geçen, onlara teslim olan askerî personel (BTS 2000).

Anekdotçik (Анекдотчик): Sovyet rejimine muhalif içerikli fikra anlatma suçundan hüküm giyen suçlulara verilen isim (TSYAS 1998).

Antisovetçik (Антисоветчик): Antisovyet siyaset yürüten, antisovyet propagandası yapan, bu sebeple baskı ve cezalara maruz kalan kimse (Bol'şoy tolkovıy slovar' russkih suşçestvitel'nıh [BTSRS] 2009).

Posobnik (Пособник): En yakın yardımcı (Suç teşkil eden bir işte), iştirakçi.

Podkulaçnik (Подкулачник): Kӧуün sınıf sistemi şartlarında kulak ${ }^{2}$ 'ın çıkarları doğrultusunda hareket eden kimse (TSU 1935-1940).

\footnotetext{
${ }^{2}$ Kulak (кулак): Fakir köylülerin emeğini sömüren zengin köylü.
} 
Hanife SARAÇ, “Sovyet Rusya'da 'Öteki'nin Yeniden İnşası Sürecinde Olumsuz Adlandırmalar”, Mavi Atlas, 7(2)/2019: 201-219

Antiobş̧̧estvennik (Антиобщественник): Sovyet toplumunun çıkarlarına ters faaliyetler yürüten kimse (TSYAS 1998).

Sabotajnik (Саботажник): Sabotaj yapan kimse, sabotajc1. Sovyet lehine gerçekleştirilen her türlü faaliyeti sabote etme çabasında olan kişi (MAS 1981-1984).

Tserkovnik (Церковник): Sözcük önceleri 'Kilise mensubu veya kiliseye hizmet eden kimse' anlamına gelirken Sovyet Dönemi'nde rejim yanlıları tarafından 'Dini hurafelere inanan, kiliseyi destekleyen kişi, gerici' anlamında kullanılmaya başlanmıştır (TSU 1935-1940).

Rvaç (Рвач): Yaptığı işten her türlü vicdansız yolu kullanarak mümkün olduğunca çıkar sağlamaya çalışan kimse (TSU 1935-1940).

Progulşçik (Прогульщик): Geçerli bir sebep göstermeksizin kasıtlı olarak işe gelmeyen kimse.

Podtasovşçik (Подтасовщик): Üstlerinin gözüne girerek güvenini kazanmak, terfi ettirilmek ya da olası cezaları bertaraf etmek için devletin yüksek organlarına yazmış olduğu raporlarda gerçekleri olduğu gibi yansıtmayan, kimi zaman abartılı rakamlar yazan, yerine getirilmeyen görevleri yerine getirilmiş gibi gösteren kimse.

Şkurnik (Шкурник): Çıkarları uğruna her türlü ahlâkî kaideyi çiğnemeye, bu uğurda bütün yolları mübah saymaya hazır, çıkarcı kimse (TSU 1935-1940).

Anonimşçik (Анонимщик): Birini karalamak, suçlamak amacıyla devlet organlarına anonim mektuplar yazan kimse (BTSRS 2009).

Pritvorş̧̧ik (Притворщик): Birini kandırmak maksadıyla kendini yalandan ... göstermek; ... a vurmak; ... mış gibi yapmak.

Oboroten'(Оборотень): Mitolojik görüşlerde, masallarda sahip olduğu sihir yeteneğini kullanarak bir kişiye ya da nesneye dönüşebilen varlık. Sözcük, Sovyet zamanında çıkarları doğrultusunda istediği kılığa girebilen, kendisini olduğundan farklı gösteren kimse anlamı kazanmıştır (TSU 1935-1940).

Naçetçik (Начетчик): Çok okuyan fakat okuduklarına eleştirel yaklaşmayan, sorgulamayan, olduğu gibi kabul eden kimse (TSYAS 1998).

Nayomnik (Наёмник): Belirli bir ücret karşılığında suç işlemeye hazır kimse.

Nauşnik (Наушник): Birine gizliden gizliye iftira atan, birinin dedikodusunu yapan kimse, jurnalci (TSU 1935-1940). 
Hanife SARAÇ, “Sovyet Rusya'da 'Öteki'nin Yeniden İnşası Sürecinde Olumsuz Adlandırmalar”, Mavi Atlas, 7(2)/2019: 201-219

Prihvosten' (Прихвостень): Birini pohpohlayarak, yaltaklık yaparak güvenini, sempatisini kazanmaya çalışan kimse (BTS 2000).

Погромщик (Pogromşçik): Soykırıma iştirak eden kimse. Uç gerici, şoven (TSU 1935-1940).

Pyotr Çervinski'nin ikinci grupta yer verdiği sözcükler yine Sovyet rejimine ters düşen olguları işaret etmekte ve bununla birlikte eylemin yapılış biçiminden ziyade bizatihi kendisi eleştirilmektedir:

Fartsovşçik (фарцовщик): Sovyet mağazalarında bulunmayan malları illegal yollarla ülkeye getirip Sovyet vatandaşlarına yüksek fiyattan satan kişilere verilen ad (Ruskkiy semantiçeskiy slovar' [RSS] 1998- 2003).

Prijival'şçik (Приживальщик): Başkasının sırtından geçinen, bunu yaparken o kişiye yaranmaya çalışan, yaltaklık eden kimse (TSU 1935-1940).

Byurokrat (Бюрократ): 1. Bürokratik yönetim sisteminin temsilcisi. 2. Vatandaşların çıkarlarının zarara uğraması pahasına yetkilerini kötüye kullanan veya formalitelere aşırı önem atfeden, k11ı kırk yaran kamu çalışanı, formalist (MAS 19811984).

Zakonnik (законник): İşin içeriğinden ziyade formâl yönlerine aşırı titizlik gösteren, biçimci, bürokrat (BTS 2000).

Bu bağlamda ilk grup (devletin yani sistemin ağzından) sosyalizmin işleyiş̧ine engel olan yaşam biçimini eleştirirken, ikinci grup (dejenere olmamış, iyi insanların ağzından) kötüleri yani bozulmuş olanları, sistemin istemediği davranışlar sergileyenleri eleştirmektedir (Çervinski 2012: 32).

Pyotr Çervinski'nin üçüncü grubu gizli, maskeli, açık olmayan, kimi zaman ikircikli Sovyet etkisi olarak adlandırılabilecek sözcükleri içermektedir. Bu türden olumsuz adlandırmaların işaret ettiği olgular Sovyetler Birliği'nde diğer ülkelere oranla daha sert bir biçimde eleştirilmiştir:

Glubinşçik (глубинщик): Devlet organlarına iletmek üzere başkalarının sırları, özel hayatları dâhil olmak üzere derin araştırmalar yapan kimse (Çervinski 2012: 34).

Gutalinşçik (гуталинщик): İ. Stalin için kullanılan bir adlandırmadır. İ. Stalin'in ayakkabı tamircisi olan babasına atıfla Rusça ayakkabı boyası anlamına gelen gutalin (гуталин) sözcüğünden türetilmiştir (Çervinski 2012: 34). 
Hanife SARAÇ, “Sovyet Rusya'da 'Öteki'nin Yeniden İnşası Sürecinde Olumsuz Adlandırmalar”, Mavi Atlas, 7(2)/2019: 201-219

Kerosinşçik (керосинщик): Gaz yağı satıcısı. Azmettirici, provakatör. Yanan ateşe benzin döken (Çervinski 2012: 34).

Sışçik (сыщик): Kişi, nesne ve olaylar, süreçler hakkında gizlice bilgi toplayan, araştırma yapan kimse (Çervinski 2012: 34).

Zahrebetnik (захребетник): Bir işte çalışmayıp başkalarının üzerinden geçinen, asalak, otlakçı. Tembelliği, ihmalciliği ya da kayıtsızlığı yüzünden başkaları üzerinden geçinen kimse (TSU 1935-1940).

Lokator (локатор): Genellikle jurnallemek amacıyla gizlice dinleme yapan kimse (Çervinski 2012: 34).

Podpevala (подпевала): Çıkarları doğrultusunda birilerini destekleyen, yaranmaya çalışan kimse (TSU 1935-1940).

Zver' (зверь): Hayvan, kan emici. İnsanları asılmaları suretiyle ölüm cezasına çarptıran ya da ölüm cezasına çarptırılanları öldürmekle görevli olan kimse (Yefr 2000).

Pyotr Çervinski'nin dördüncü gruba dâhil ettiği sözcükleri doğrudan Sovyet dönemiyle ilişkilendirmek mümkün değildir. Bu sözcükler Sovyet Dönemi’nde anlam genişlemesi yoluyla başka hiçbir dönemde olmadığı kadar eleştiri içeren yeni anlamlar (rejimin olumlamadığı özellikleri içeren) kazanmıştır. Örneğin geveze anlamına gelen govorun (говорун) sözcüğ̈ Sovyet bağlamında yalnızca "konuşmayı seven" anlamına gelmemekte, gevezeliği işine, sosyalist düzene, topluma, sosyalizm davasına, Sovyet devletine zarar veren kişiler için kullanılmaktadır (Bol'şoy Tolkovıy, 2000). Yine çı̆̆ırtkan anlamına gelen krikun (крикун) sözcüğ̈̈ yalnızca bir sebep olmaksızın çok bağıran anlamında değil, kitlelere hitap ederken insanların dikkatini çekerek iktidarın belirlediği çizgilerin dışına çıkan, çıkarlarına zarar veren, ideolojinin onaylamadığı, doğru bulmadığ konuşmalar yapan kimse anlamına gelmektedir (Çervinski 2012: 49). İlk anlamı net olmayan, hırıltılı sesle konuşan ya da şarkı söyleyen olan hripun (хрипун) sözcüğü ise zamanla Sovyet yaşam biçimini kabullenmeyen, onaylamayan, var olan gerçekliği ve Sovyet yapısını yeren, antisovyet propagandası yapan kişi anlamı kazanmıştır (Çervinski 2012: 58). Keza Russkaya grammatika adlı kitapta 1970'lerin sonuna doğru ortaya çıktığı iddia edilen (Russkaya Grammatika 1980: 14) nesun (несун) sözcügü, küçük hırsızlıklar yapan, çalıştığı işyerinden bir şeyler aşıran (Bolşoy Tolkovıy 2000), çalıştığ1 yerde üretilen ürünlerin bir kısmını izinsiz evine götüren kimse (Mokiyenko, Nikitina 1998) anlamına gelmektedir ve konuşma dilinde sıklıkla kullanılmıştır (Yefremova 1996: 476-477). 
Hanife SARAÇ, “Sovyet Rusya'da 'Öteki'nin Yeniden İnşası Sürecinde Olumsuz Adlandırmalar”, Mavi Atlas, 7(2)/2019: 201-219

Zateynik (затейник): İlk sözlük anlamı “halkı eğlendiren artist”tir. Sovyet basınında entrika çeviren yabancı politikacılar için kullanılan aşağılayıcı bir anlam kazanmıştır (Çervinski 2012: 58).

Raznosçik (разносчик): Bir şeyleri taşımakla geçimini sağlayan kişi. Sovyetlerde dedikodu yapan kimse anlamında kullanılmaya başlanmıştır. Sovyet basınında iktidarın siyasetiyle ilgili yalan yanlış haber yayan kimse anlamında kullanılmıştır (BTS 2000).

Hozyayçik (хозяйчик): Sahip. Resmi komünist literatüründe küçük, özel müteşebbisleri (örneğin bakkal, büfe vb.) aşağılama amaçlı kullanılmaktaydı. Genellikle SSCB vatandaşlarından ziyade Komünist bloğa dâhil diğer Doğu Avrupa ülkelerinin vatandaşları kastediliyordu. Çok sayıdaki özel girişimcisiyle Polonya bu durumun tipik bir örneğini oluşturuyor, bu girişimcilerin sosyalizmin inşasına engel oldukları iddia ediliyordu (MAS 1981-1984).

Nahlebnik (нахлебник): Başkalarının üzerinden geçinen kimse. Bir toprak sahibinin ya da beyin yanında karın tokluğuna kalan kimse (BTS 2000).

Sanovnik (сановник): Devlette yüksek mevki sahibi, nüfuzlu kimse. Ekim Devrimi'nden önce de kullanılan, devrimden sonra bağlama göre halkın mesafeli durduğu iktidarın ileri gelenleri için kullandığı bir sözcüktür (TSU 1935-1940).

Mirotvorets (миротворец): Sözcüğün çok sayıda anlamı bulunmaktadır, farklı zamanlarda değişik anlamlarda kullanılmıştır. Önceleri resmi basında barış için çabalayan, savaş karşıtı Sovyet lideri şeklinde yer almıştır. İlk anlamlarından biri savaş ve şiddetin yanlış olduğunu savunan, savaşı desteklemeyen kişidir ancak sözcüğün Sovyetize edilmiş anlamlarından biri barış savunucusu maskesinin ardına gizlenerek aslında savaş hazırlığı içinde olan ve düşmanı yok etme planları yapan kimsedir (Tolkoviy slovar' russkogo yazıka kontsa XX [TSRYAXX]).

Kutila (кутила): Çalışmayı sevmeyen, tembel, eğlence düşkünü (MAS).

Çinovnik (чиновник): Ekim Devrimi öncesi Rusya'sında ve burjuva ülkelerinde devlet çalışanı. Bazı bağlamlarda işini emir gereği, formalite icabı, aktif bir katılım sağlamaksızın yerine getiren kimse anlamında kullanılmaktadır (TSU 1935-1940).

Barin (барин): Ekim Devrimi öncesinden kalan ve o zamanlar beyefendi anlamında kullanılan bir sözcüktür. Sovyet Rusya'da devletin önemli kademelerinde görev alan kişiler ve halk arasındaki uçurumu ve sıradan halkın serf ve köle, barinin ise bu kesimin yeni sahibi olduğunu göstermek amaciyla kullanılan bir adlandırmadir (MAS). 
Figurant (фигурант): Genellikle dela (дела) sözcüğ̈̈yle birlikte (фигурант дела) kullanılmaktadır. Bir suç isnat edilen kimse. Bazen de uluslararası finansal ya da siyasi krize neden olan yabancı bir politikacı için de kullanılmıştır.

Jivoder (живодер): İlk anlamı hayvanlara eziyet eden kişi olan sözcük Sovyetlerde çok zalim kişiler için de kullanılmıştır (Yefr 2000).

Mandarin (мандарин): Rusça'ya Çince'den geçmiş bir sözcüktür. Bürokrat, memur gibi devlet çalışanları için kullanılmaktadır. Sovyetlerde işini formalite icabı, fazla özenmeden, ruhsuzca yapan kişiler için kullanılmıştır.

\section{Sonuç}

Rusya'da 1917 y1lında gerçekleşen Ekim Devrimi’yle birlikte “öteki”nin yeniden tanımlanmasına, tesis edilmesine ihtiyaç duyulmuştur. Zira sosyal, kültürel, dini hayat kurulan yeni düzenle birlikte tamamen değişmiştir. Sosyalist iktidar yeni düzenin devam1 için gerekli olan mayanın grup içi bütünleşme olduğunun bilinciyle daha sonra düşmana evrilecek olan “öteki”nin oluşumu ve temsili üzerinde çalışmıştır.

Devingen bir yapıya sahip olan “öteki”, propaganda üzerinden zihinlere işlenir. Ötekileştirmenin en temel aracı dildir, ötekinin sınırları dil yoluyla belirlenir. Çeşitli imgeler, yaftalama sözcükleri, adlandırmalarla oluşturulan söylemler üzerinden halkın bilinçaltına yerleştirilir. Ötekileştirme mekanizmasında genellikle dil, din, rrk, cinsiyet gibi olgular kullanılmasına rağmen, Sovyetler Birliği'nde genelde iç ve dış düşman unsurları yer almıştır. İlk etapta rejim için tehdit oluşturdukları iddiasıyla kapitalistler dış düşman olarak gösterilirken, devrimin yerleşmesinden sonra iç düşmana yoğunlaşılmıştır. İç düşman imgesi daha dinamik ilerlemiş; koşullara bağlı olarak sürekli yenilenmiştir. İç Savaş sırasında söylem yoluyla kurulan dışlama mekanizması daha sonra sözcüksel düzeyde kendisini göstermiştir. İç Savaş yılları ve arifesinde daha çok Bolşevik liderlerin demeçlerinde yer alan stereotipsel söylemler ve değer atıfları göze çarpmaktadır. Diğer bir deyişle öteki mekanizmasının sosyalist sistem tamamen oturmadan önce söylem üzerinden, sonra ise daha çok yaftalama sözcükleri üzerinden oluşturulduğu söylenebilir.

"Biz ve "öteki" arasındaki sınırların belirlenmesine hizmet eden olumsuz adlandırmalar, yaratacakları algıyla kolektif bilince şekil vermek, rejimin değerlerini benimsetmek, basmakalıp temsillerle “öteki”nin sistemin çürükleri olduğu intibasını yaratmak, sosyalist sistemin içeriğine aykırı davranış kalıpları geliştirenleri anormal, 
Hanife SARAÇ, “Sovyet Rusya'da 'Öteki’nin Yeniden İnşası Sürecinde Olumsuz Adlandırmalar”, Mavi Atlas, 7(2)/2019: 201-219

toplum ve vatan çıkarlarına kayıtsız kimseler olarak göstermek gibi işlevleriyle Sovyet iktidarına yarar sağlamıştır.

\section{Kaynakça}

ANNENKOV, Yuri (1991). Dnevnik moih vstreç, Leningrad: İskusstvo, T.2.

BİLGİN, Nuri (1996). Insan İlişkileri ve Kimlik, İstanbul: Sistem Yayıncılık.

Bol'şoy tolkovly slovar' russkogo yazıka (2000). Gl. Red. S.A. Kuznetsov, SanktPeterburg: Norint.

Bol'şoy tolkovıy slovar' russkih suşçestvitel'nıh (2009), Moskva: Ast-press.

CAN EMİR, Badegül (2019). Rus Edebiyatında Birinci Dünya Savaşı (Tarihsel Perspektif Işı̆̆ıında), İstanbul: Değişim Yayınları.

ÇERVINSKİ, Pyotr (2012). Negativno otsenoçnıye leksemı yazıka sovetskoy deystvitel'nosti oboznaçeniye lits, Riga: Palmarium Academic Publishing.

ÇETIN, Halis (2002 Mayıs). "Totalitarizm: İdeolojik ve Toplumsal İnşa Araçları", C.Ü. Sosyal Bilimler Dergisi, No.1: 15-43.

ERGUN, Pervin (2013). “Türk Kültüründe Ölümle İlgili Bazı Terimler”, Millı̂ Folklor, 100: 134-148.

HAYEK, Friedrich August von (1999). Kölelik Yolu, çev. Turhan Feyzioğlu ve Yıldıray Arsan, Ankara: Liberte Yayıncilık.

ELLUL, Jaques (1973). Propaganda: The Formation of Men's Attitudes, New York: Vintage Books.

KRISKO, Vladimir (1999). Sekretı Psihologiçeskoy Voynı, Minsk: İzdatel'stvo 'Harvest'.

KOROBKOVA, Olga (2011). “'Svoi-Çujiye' v derolyutsionnom politiçeskom diskurse bol'şevikov i sovetskom totalitarnom diskurse", Politiçeskaya kommunikatsiya, 4(38): 97-103.

Kratkiy Kurs (1950). İstoriya Vserossiyskoy Kommunistiçeskoy Partii Bol'şevikov (Pod. red. Komis. TSK VPK), Moskva: Politizdat.

LENIN, Vladimir (1967). Polnoye sobraniye soçineniy, T.8., Moskva: İzdatel'stvo politiçeskoy literaturı. 
Hanife SARAÇ, “Sovyet Rusya'da 'Öteki'nin Yeniden İnşası Sürecinde Olumsuz Adlandırmalar”, Mavi Atlas, 7(2)/2019: 201-219

LENIN, Vladimir (1978). Polnoye sobraniye soçineniy, T.51., Moskva: İzdatel'stvo politiçeskoy literaturı.

LENIN, Vladimir (1918). "O demokratii i diktature", Polnoye sobraniye soçineniy (izdaniye pyatoye), T. 37., Moskva: İzdatel'stvo politiçeskoy literaturı, str. 388393.

MOKIYENKO, Valeriy; NIKİTINA, Tatyana (1998). Tolkovıy slovar' yazıka sovdepii, Harkov: Folio-press.

OJEGOV, Sergey (1952). Slovar' russkogo yazıka, Moskva: Gosudarstvennoye izdatel'stvo inostrannıh i natsional'nıh slovarey izdatel'stvo.

PLATON (1995). Devlet, çev. Sebahattin Eyüboğlu ve M. Ali Cimcoz, İstanbul: Remzi Kitabevi.

Ruskkiy semantiçeskiy slovar'. Tolkovly slovar', sistematizirovanniy po klassam slov i znaçeniy (2003). Pod obşçey red. N. Yu. Şvedovoy. T. I (III), Moskva: RAN İnstitut russkogo yazıka.

SAKALLI, Nuray (2010). Sosyal Etkiler: Kim, Kimi Nasıl Etkiler?, 3. Basım, Ankara: İmge Kitabevi.

SIMMEL, George (1956). Conflict and the Web of Group Affiliation, Glencoe: Free Press.

Slovar' russkogo yazıka v 4-h tomah (1981-1984). Гл. ред. A.P.Yevgenyeva, 2-oe izd., Moskva: Russkiy yazık.

STALIN, İosif (1946). "Burjuaziya stavit lovuşku”, Soçineniya, T.1., Moskva: OGİZ, Gosudarstvennoye izdatel'stvo politiçeskoy literaturı, s. 179-184.

STALİN, İosif(1949). Soçineniya, T 12, Moskva: Gosudarstvennoye izdatel'stvo $\begin{array}{lllll}\text { politiçeskoy } & \text { literaturı, } & \text { Erişim } & \text { Tarihi: } & \text { Ağustos }\end{array}$ (http://grachev62.narod.ru/stalin/t12/t12_01.htm).

Tolkovly slovar' russkogo yazıka kontsa XX v. Yazıkovlye izmeneniya (1998). Gl. Red. G. N. Sklyarevskaya, Sankt-Peterburg: Rossiyskaya Akademiya Nauk, İnstitut lingvistiçeskih issledovaniy.

Tolokoviy slovar' russkogo yazıka (1935-1940). Pod. red. D.N.Uşakova (t. I-IV), Moskva: Gos. İn-t 'Sov. Entsikl', OGİZ, Gos. İzd-vo inostr. i nats. slov. 
Hanife SARAÇ, “Sovyet Rusya'da 'Öteki’nin Yeniden İnşası Sürecinde Olumsuz Adlandırmalar”, Mavi Atlas, 7(2)/2019: 201-219

UŞAKOV, Dimitri (2006). Bol'şoy Tolkovıy slovar' sovremennogo russkogo yazıka, Moskva: Al'ta-Print.

ÜNÜR, Ece (2013). “Görünmeyen Kimlikler: Öteki Kimliği Bağlamında "Kayıp Şehir” Dizisinin Analizi”, Akademik Incelemeler Dergisi, 2: 251-273.

YEFREMOVA, T. F. (2000). Novly slovar' russkogo yazıka, Tolkovoslovoobrazovatel'nıy (т. 1-2), Moskva: Russkiy yazık.

ZDRAVOMISLOV, Andrey (1996). Sotsiologiya konflikta, Moskva: Aspekt Press. 